The American Journal of Chinese Medicine, Vol. 30, Nos. 2 \& 3, 271-285

(C) 2002 World Scientific Publishing Company

\& Institute for Advanced Research in Asian Science and Medicine

\title{
The Effect of Chinese Medicine on Bone Cell Activities
}

\author{
Chun-Yu Lin, ${ }^{*}$ Jui-Sheng Sun, ${ }^{+}$Shiow-Yunn Sheu, ${ }^{*}$ Feng-Huei Lin, ${ }^{\neq}$Yng-Jiin Wang ${ }^{\S}$ and Li-Ting Chen ${ }^{+}$ \\ *School of Pharmacy, Taipei Medical University \\ ${ }^{+}$Department of Orthopedic Surgery, National Taiwan University Hospital \\ ${ }^{7}$ Institute of Biomedical Engineering, College of Medicine, National Taiwan University \\ ${ }^{\S}$ Institute of Biomedical Engineering, National Yang-Ming University \\ Taipei, Taiwan, R.O.C.
}

(Accepted September 27, 2001)

\begin{abstract}
In this experiment, we investigate the biochemical effects of traditional Chinese medicines via an in vitro bone cell culture. Ten different Chinese medicines were used in this study. The rat osteoblast-osteoclast co-culture system was used as the experimental model. After the cells grew to $80 \%$ confluence, various tested materials were added. The mitochondria activity of the bone cells after exposure to various preparations of Chinese medicines was determined by colorimetric assay. Biochemical markers such as protein content, lactate dehydrogenase (LDH), alkaline phosphatase (ALP), and acid phosphatase (ACP) titer were analyzed to evaluate the bone cell activity. When cultured with various Chinese medicines for 24 hours, only four of these ten Chinese medicines had potential beneficial effects on the bone cell culture; and only Drynaria fortunei (Kunze) J. Sm. had a universal beneficial effect on bone cell metabolism. The major beneficial effect of Drynaria fortunei (Kunze) J. Sm. on bone cells is probably mediated by the induction of apoptosis of the osteoclast cell population. Continued study of alterations in gene expression of bone cells caused by Chinese medicines will improve our understanding of bone cell responses to various pharmacological interventions.
\end{abstract}

Keywords: Osteoblast; Osteoclast; in vitro; Chinese Medicine; Apoptosis.

\section{Introduction}

Osteoporosis is a major healthcare problem of aging communities. Its clinical significance lies in the fractures that arise, most commonly of the forearm, the vertebral bodies, and the hip. Of these, the most serious is hip fracture because of the high morbidity and associated

Correspondence to: Dr. Jui-Sheng Sun, Department of Orthopedic Surgery, National Taiwan University Hospital, No. 7, Chung-Shan South Road, Taipei, Taiwan, R.O.C. Tel: 8862-2312-3456 (ext. 3957), Fax: 8862-23224112 E-mail: drjssun@ccms.ntu.edu.tw 
mortality and consequent high cost to health services (WHO Technical Report Series No. 843 , 1994). Vertebral, forearm, and upper humeral fractures also cause considerable morbidity and, since they tend to occur in younger individuals than hip fractures, have significant long-term impact on quality of life (Crane et al., 1995).

The events that take place in the healing of the fracture involve various tissues including the bone itself, periosteum, endosteum, marrow and the soft tissues adjacent to the fracture (Campbell, 1969). The fibroblasts, osteoblasts and osteoclasts in the fracture site are actively engaged in the synthesis and secretion of collagen, which takes the form of fibrils of varying diameter within the wound site (Smith, 1980). For the repairing of skeletal defects, osteoblasts should populate the defects by proliferation of the transplanted cells and the migration of cells into the defect from the surrounding tissue while the interposing soft tissue gradually degrades. Eventually the construct will be filled with calcified extracellular matrix secreted by the osteoblasts. Healing of large osseous defects is crucial to success of many orthopedic procedures.

The osseous defects and fractures may require supplementation to promote healing. Stimulation of osteogenesis leading to bone repair, as in patients with large bone defects, fracture non-unions, and incomplete allograft consolidation, is clinically desirable for early healing and restoration of function. There are several traditional Chinese medicines commonly used to manage disorders of orthopedics and were alleged to have obtained satisfactory results. In this experiment, we investigate their biological effects via the in vitro bone cell culture.

\section{Materials and Methods}

\section{Preparation of Chinese Medicines}

The Chinese medicines used in this study were supplied in dry form by the School of Pharmacy, Taipei Medical University, Taiwan, R.O.C. Their identification were authenticated by experts in pharmacognosis as shown in Table 1 . The procedures for extraction of these crude drugs were standardized. Briefly, $500 \mathrm{~g}$ of crude drugs were extracted by $70 \%$ acetone for three times, filtered to remove insoluble debris and concentrated in $40^{\circ} \mathrm{C}$ and vacuum evaporation. Then the mid-products were freeze-dried to get final products used in this experiment. In the text, these medications were summarized as CHD-1: Drynaria fortunei (Kunze) J. Sm.; CHD-2: Eupolyphaga sinensis Walker; CHD-3: Dipsacus asper Wall.; CHD-4: Achyranthes bidentata B1.; CHD-5: Eucommia ulmoides Oliv.; CHD-6: Pyrite (FeS2); CHD-7: Panax psedoginseng Wall. var. notoginseng (Burkill); CHD-8: Rehmannia glutinosa (Gaertn.) Libosch.; CHD-9: Commiphora myrrha Engl.=C. molmol Engl.; and CHD-10: Carthamus tinctorius L.

In the first part of this study, the effects of various Chinese medicines on bone cell activities were established by using MTT assay as described below. Seven different concentrations of various Chinese medicines $(10 \mathrm{mg}, 1 \mathrm{mg}, 100 \mu \mathrm{g}, 10 \mu \mathrm{g}, 1 \mu \mathrm{g}, 100 \mathrm{ng}$ and $10 \mathrm{ng} / \mathrm{ml}$ ) were tested for 1 day, 3 day and 7 day periods. 
Table 1. Different Chinese Medicines Used to Evaluate Its Effect on the Bone Cell Activities

\begin{tabular}{ll}
\hline CHD-1 & Drynaria fortunei (Kunze) J. Sm. \\
CHD-2 & Eupolyphaga sinensis Walker \\
CHD-3 & Dipsacus asper Wall. \\
CHD-4 & Achyranthes bidentata B1. \\
CHD-5 & Eucommia ulmoides Oliv. \\
CHD-6 & Pyrite (FeS2) \\
CHD-7 & Panax psedoginseng Wall. var. notoginseng (Burkill) \\
CHD-8 & Rehmannia glutinosa (Gaertn.) Libosch. \\
CHD-9 & Commiphora myrrha Engl. \\
CHD-10 & Carthamus tinctorius L. \\
\hline
\end{tabular}

\section{Osteoblast/Osteoclast Bone Cell Culture}

The rat alveolar mononuclear cells-calvarias osteoblasts co-culture system was the same as previously described (Sun et al., 2000). Newborn Wistar rats (three- to five-days-old) were obtained from the laboratory center of the Medical College, National Taiwan University. Primary osteoblastic cells were prepared from newborn rat calvarias. Osteoblastic cells $\left(1 \times 10^{4}\right.$ cells/well $)$ and alveolar mononuclear cells $\left(7.5 \times 10^{5}\right.$ cells/well $)$ were co-cultured for 6 days in Dulbecco's modified Eagle's medium supplemented containing $10 \%$ fetal calf serum (Gibco, UK), in the presence of $10 \mathrm{nM} 1 \alpha, 25(\mathrm{OH})_{2} \mathrm{D}_{3}$ in six-well plates. Penicillin G sodium 100 units $/ \mathrm{ml}$ and streptomycin $100 \mu \mathrm{g} / \mathrm{ml}$ (Gibco, UK) were added. The culture dishes were incubated at $37^{\circ} \mathrm{C}$ in an atmosphere supplemented with $5 \% \mathrm{CO}_{2}$. After the cells grew to $80 \%$ confluence, various tested Chinese medicines were added.

\section{Colorimetric MTT (Tetrazolium) Assay for Cell Viability (Mosmann, 1983)}

The mitochondria activity of the bone cells after exposure to various preparations of Chinese medicines was determined by colorimetric assay which detects the conversion of 3-(4,5dimethylthiazolyl-2)-2,5-diphenyltetrazolium bromide (MTT, Sigma catalog no. M2128, Sigma Co., St. Louis, MO, USA) to formazan. For the assay, $2.5 \times 10^{4}$ cells per well were incubated $\left(5 \% \mathrm{CO}_{2}, 37^{\circ} \mathrm{C}\right)$ in the presence of various preparations of Chinese medicines. After various time intervals the supernatant was removed, $100 \mu \mathrm{l}$ per well of MTT solution $\left(1 \mathrm{mg} / \mathrm{ml}\right.$ in test medium) was added and the wells were incubated at $37^{\circ} \mathrm{C}$ for 4 hours to allow the formation of formazan crystal. Again, the supernatant was removed and acidisopropanol (100 $\mu \mathrm{l}$ of $0.04 \mathrm{~N} \mathrm{HCl}$ in isopropanol) was added to all wells and mixed thoroughly to dissolve the dark blue crystals. After a few minutes at room temperature to ensure that all crystals were dissolved, the plates were read on Micro Elisa reader (Emax Science Corp., Sunnyvale, California, USA), using a test wavelength of $570 \mathrm{~nm}$ against a reference wavelength of $690 \mathrm{~nm}$. Plates were normally read within 1 hour after adding the isopropanol. 


\section{Total Protein in Culture Medium}

Total protein released from the cells into the medium was measured by modified micro Lowry methods with a commercially available assay kit (Procedure no. 690-A, Sigma Co., St. Louis, MO, USA). Briefly, an aliquot $(20 \mu \mathrm{l})$ from the media was mixed with $250 \mu \mathrm{l}$ Biuret reagent. The absorbance at $550-750 \mathrm{~nm}$ caused by purple-blue complex was read at $25^{\circ} \mathrm{C}$. The titer of protein was determined from a standard curve.

\section{Analysis of Lactate Dehydrogenase in Culture Medium}

Lactate dehydrogenase (LDH) activity released from the cells into the medium was measured with a commercially available assay kit (Procedure no. 228-UV, LDL-10, Sigma Co., St. Louis, MO, USA). Briefly, an aliquot $(10 \mu \mathrm{l})$ from the media was mixed with $200 \mu \mathrm{LDH}$ reagent. The absorbance at $340 \mathrm{~nm}$ caused by nicotinamide adenine dinucleotide (NAD) production was followed for 5 minutes at $30^{\circ} \mathrm{C}$. The change in rate of absorbance was directly proportional to LDH activity.

\section{Analysis of Alkaline Phosphatase in Culture Medium}

Alkaline phosphatase (ALP) activity released from the cells into the medium was measured with a commercially available assay kit (procedure no. ALP-10, Sigma Co., USA). Briefly, an aliquot $(5 \mu \mathrm{l})$ from the media was mixed with $250 \mu \mathrm{l}$ alkaline phosphatase reagent. The absorbance at $405 \mathrm{~nm}$ caused by p-nitrophenol production was followed for 5 minutes at $30^{\circ} \mathrm{C}$. The change in rate of absorbance was directly proportional to ALP activity.

\section{Analysis of Acid Phosphatase in Culture Medium}

Acid phosphatase (ACP) activity released from the cells into the medium was measured with a commercially available assay kit (Procedure no. 435, ACP, leukocyte, Sigma Co., St. Louis, MO, USA). Briefly, an aliquot $(20 \mu \mathrm{l})$ from the media was mixed with $200 \mu \mathrm{l}$ acid phosphatase reagent. The absorbance at $405 \mathrm{~nm}$ caused by p-nitrophenol production was followed for 5 minutes at $30^{\circ} \mathrm{C}$. The change in rate of absorbance was directly proportional to ACP activity.

Analysis of Cytoplasmic Total Protein, Lactate Dehydrogenase, Alkaline Phosphatase and Acid Phosphatase

At the end of the experimental period, intracellular total protein, LDH, ALP and ACP activity was determined following lysis of the cells with the detergent Triton X-100 (Sigma T 8787, Louis, MO, USA; $1 \%$ in Hanks' balanced salt solution, $30 \mathrm{ml}$ at $37^{\circ} \mathrm{C}$ ). Cytoplasmic ALP, $\mathrm{ACP}$ and LDH values were determined as the methods described for the measurements of culture media. 


\section{Statistical Analysis}

The differences between various samples were evaluated by an analysis of variances statistic method. The post-hoc test performed was Bonferroni's t test. The level of statistical significance was defined as $\mathrm{p}<0.05$.

\section{Immunohistochemical Detection of Apoptosis}

Detection of apoptosis in bone cells after Chinese medicines treatment was performed by the immunohistochemical methods described by Sgonc et al. (1994). For the assay, $1.0 \times$ $10^{5}$ cells $/ \mathrm{ml}$ in $9.4 \mathrm{~cm}^{2}$ culture dish were incubated $\left(5 \% \mathrm{CO}_{2}, 37^{\circ} \mathrm{C}\right)$ in the presence of various Chinese medicines. After various time intervals the supernatants were removed, cell samples were fixed with paraformaldehyde solution (4\% in PBS, $\mathrm{pH} 7.4$ ) for 30 minutes at room temperature. The endogenous peroxidase was blocked by $0.3 \% \mathrm{H}_{2} \mathrm{O}_{2}$ then permeated with $0.1 \%$ Triton ${ }^{\circledR} \mathrm{X}-100$ in $0.1 \%$ sodium citrate (Boehringer Mannheim, Mannheim, Germany) for 2 minutes on ice $\left(4^{\circ} \mathrm{C}\right)$. The DNA strand breaks in bone cells were then fluorescence-labeled by $100 \mu \mathrm{l}$ TUNEL (TdT-mediated dUTP nick end labeling) reaction mixture (Boehringer Mannheim, Mannheim, Germany) and incubated for 60 minutes. Antifluorescence antibody conjugated with peroxidase (Boehringer Mannheim, Mannheim, Germany) was added and then incubated with samples for 30 minutes. DAB-substrate solution was added and incubated for 10 minutes. Samples were then analyzed under light microscope.

\section{Results}

\section{Bone Cell MTT Viability Test}

3-(4,5-dimethylthiazolyl-2)-2,5-diphenyltetrazolium bromide (MTT) is a pale yellow substrate that produces a dark blue formazan product when incubated with living cells. MTT ring is cleaved in active mitochondria, and the reaction occurs only in living cells (Mosmann, 1983). Table 2 shows the effect of various Chinese medicines on bone cell viability measured by MTT assay. When cultured with various Chinese medicines for 24 hours, CHD-1, -2 and -6 showed beneficial effects to bone cell viability. When the culture period increased to 3 or 7 days, CHD-10 also manifested with significant increase in bone cell viability (Table 2). In this study, we selected the concentration of $1 \mathrm{mg} / \mathrm{ml}$ for CHD-1 and -10 , while for CHD-6, $100 \mu \mathrm{g} / \mathrm{ml}$, and for CHD-2, $1 \mu \mathrm{g} / \mathrm{ml}$ was selected for further evaluation of bone cell activities. 
Table 2. Effect of Various Chinese Medicines on Bone Cell Viability Measured by MTT Assay

\begin{tabular}{|c|c|c|c|c|c|c|c|c|c|c|c|c|}
\hline & CHD-1 & & CHD-3 & & CHD-5 & & CHD-7 & & CHD-8 & & CHD-10 & \\
\hline day & Mean & S.D. & Mean & S.D. & Mean & S.D. & Mean & S.D. & Mean & S.D. & Mean & S.D. \\
\hline ontrol & 0.377 & 0.059 & 0.153 & 0.031 & 0.096 & 0.0225 & 0.138 & 0.020 & 0.110 & 0.014 & 0.168 & 0.021 \\
\hline $10 \mathrm{mg}$ & $0.188^{\neq}$ & 0.056 & 0.134 & 0.024 & 0.081 & 0.0307 & $0.094^{\neq}$ & 0.019 & 0.101 & 0.057 & $0.096^{\neq}$ & 0.012 \\
\hline $1 \mathrm{mg}$ & $0.676^{\neq}$ & 0.187 & 0.159 & 0.033 & 0.090 & 0.0171 & 0.141 & 0.025 & 0.101 & 0.014 & 0.187 & 0.039 \\
\hline $100 \mu \mathrm{g}$ & 0.341 & 0.027 & 0.161 & 0.040 & 0.088 & 0.0122 & 0.140 & 0.024 & 0.118 & 0.036 & 0.187 & 0.034 \\
\hline $10 \mu \mathrm{g}$ & 0.380 & 0.055 & 0.153 & 0.028 & 0.095 & 0.0182 & 0.132 & 0.014 & 0.104 & 013 & 0.188 & 0.038 \\
\hline $1 \mu \mathrm{g}$ & 0.365 & 0.059 & 0.151 & 0.023 & 0.092 & 0.0144 & 0.138 & 0.017 & 0.113 & 0.021 & 0.174 & 0.014 \\
\hline $100 \mathrm{ng}$ & 0.388 & 0.081 & 0.162 & 0.041 & 0.088 & 0.0082 & 0.136 & 0.0128 & 0.118 & 0.035 & 0.174 & 0.027 \\
\hline $10 \mathrm{ng}$ & 0.383 & 0.046 & 0.147 & 0.033 & 0.107 & 0.0268 & 0.133 & 0.026 & 0.1214 & 0.026 & 0.169 & 0.028 \\
\hline ANOVA & $<0.0001$ & & 0.5996 & & 0.2152 & & $<0.0001$ & & 0.6404 & & $<0.0001$ & \\
\hline days & Mean & S.D. & Mean & S.D. & Mean & S.D. & Mean & S.D. & Mean & S.D. & Mean & S.D. \\
\hline Control & 0.4838 & 0.058 & 0.161 & 0.032 & 0.100 & 0.012 & 0.128 & 0.011 & 0.183 & & 0.266 & 0.026 \\
\hline $10 \mathrm{mg}$ & $0.145^{\neq}$ & 0.024 & 0.141 & 0.097 & 0.075 & 0.044 & $0.094 *$ & 0.042 & $0.093^{+}$ & 0.022 & $0.151^{\neq}$ & 0.073 \\
\hline $1 \mathrm{mg}$ & $0.883^{\neq}$ & 0.076 & 0.192 & 0.063 & $0.114^{*}$ & 0.019 & 0.122 & 0.021 & 0.150 & 0.020 & $0.381^{\neq}$ & 0.054 \\
\hline $100 \mu \mathrm{g}$ & 0.515 & 0.113 & $0.209^{*}$ & 0.072 & $0.122^{+}$ & 0.022 & 0.126 & 0.021 & 0.161 & 0.016 & $0.375^{+}$ & 0.094 \\
\hline $10 \mu \mathrm{g}$ & 0.457 & 0.068 & $0.195^{*}$ & 0.047 & $0.117^{*}$ & 0.012 & 0.144 & 0.044 & 0.175 & 0.028 & $0.359^{+}$ & 0.074 \\
\hline $1 \mu \mathrm{g}$ & $0.403^{+}$ & 0.030 & 0.183 & 0.026 & $0.132^{\neq}$ & 0.021 & $0.156^{+}$ & 0.034 & 0.180 & 0.057 & $0.344^{+}$ & 0.063 \\
\hline $100 \mathrm{ng}$ & 0.440 & 0.065 & $0.222^{*}$ & 0.084 & $0.131^{+}$ & 0.019 & $0.154^{\neq}$ & 0.019 & 0.174 & 0.047 & $0.328^{*}$ & 0.075 \\
\hline $10 \mathrm{ng}$ & $0.416^{*}$ & 0.039 & 0.149 & 0.018 & $0.120^{+}$ & 0.022 & 0.140 & 0.021 & $0.148 *$ & 0.019 & $0.347^{+}$ & 0.071 \\
\hline ANOVA & $<0.0001$ & & 0.0412 & & $<0.0001$ & & 0.0001 & & $<0.0001$ & & $<0.0001$ & \\
\hline 7 days & Mean & S.D. & Mean & S.D. & Mean & S.D. & Mean & S.D. & Mean & S.D. & Mean & S.D. \\
\hline Control & 0.647 & 0.085 & 0.280 & 0.042 & 0.259 & 0.035 & 0.218 & 0.023 & 0.204 & 0.087 & 0.538 & 0.192 \\
\hline $10 \mathrm{mg}$ & $0.169^{\neq}$ & 0.038 & $0.139^{\neq}$ & 0.026 & $0.085^{\neq}$ & 0.015 & $0.091^{\neq}$ & 0.012 & $0.090^{\neq}$ & 0.024 & $0.325^{*} 0$ & 0.1898 \\
\hline $1 \mathrm{mg}$ & $0.964^{\neq}$ & 0.152 & $0.334^{*}$ & 0.067 & 0.266 & 0.042 & $0.285^{\neq}$ & 0.046 & 0.218 & 0.0642 & $0.822^{\neq}$ & 0.085 \\
\hline $100 \mu \mathrm{g}$ & 0.644 & 0.076 & $0.313^{*}$ & 0.037 & 0.303 & 0.079 & $0.273^{+}$ & 0.051 & $0.297^{+}$ & 0.092 & $0.769 * 0$ & 0.1813 \\
\hline $10 \mu \mathrm{g}$ & 0.597 & 0.144 & 0.314 & 0.047 & 0.284 & 0.064 & $0.292^{+}$ & 0.045 & $0.305^{\neq}$ & 0.077 & $0.718^{+}$ & 0.178 \\
\hline $1 \mu \mathrm{g}$ & 0.574 & 0.104 & $0.355^{+}$ & 0.1011 & $0.304^{*}$ & 0.039 & $0.289^{\neq}$ & 0.049 & $0.315^{+}$ & 0.075 & $0.707 *$ & 0.110 \\
\hline $100 \mathrm{ng}$ & 0.607 & 0.137 & $0.356^{+}$ & 0.074 & 0.289 & 0.060 & $0.284^{+}$ & 0.055 & $0.339^{\neq}$ & 0.086 & 0.631 & 0.171 \\
\hline $10 \mathrm{ng}$ & $0.762 *$ & 0.165 & 0.335 & 0.121 & 0.289 & 0.035 & $0.285^{*}$ & 0.088 & $0.339^{+}$ & 0.119 & 0.5150 & 0.0683 \\
\hline \multicolumn{4}{|c|}{ ANOVA $<0.0001$} & $<0.0001$ & & $<0.0001$ & $1<0.000$ & & $<0.0001$ & & $<0.0001$ & \\
\hline
\end{tabular}


Table 2. (Continued)

\begin{tabular}{|c|c|c|c|c|c|c|c|c|c|}
\hline & CHD-2 & & & CHD-4 & & CHD-6 & & CHD-9 & \\
\hline 1 day & Mean & S.D. & 1 day & Mean & S.D. & Mean & S.D. & Mean & S.D. \\
\hline Control & 0.168 & 0.036 & Control & 0.161 & 0.021 & 0.098 & 0.022 & 0.105 & 0.012 \\
\hline $100 \mu \mathrm{g}$ & 0.179 & 0.027 & $1 \mathrm{mg}$ & $0.119^{+}$ & 0.017 & $0.182^{\neq}$ & 0.036 & 0.124 & 0.040 \\
\hline $10 \mu \mathrm{g}$ & $0.202 *$ & 0.035 & $100 \mu \mathrm{g}$ & 0.177 & 0.021 & $0.168^{\neq}$ & 0.024 & $0.133^{*}$ & 0.047 \\
\hline $1 \mu \mathrm{g}$ & 0.190 & 0.039 & $10 \mu \mathrm{g}$ & 0.194 & 0.077 & $0.189^{\neq}$ & 0.030 & 0.107 & 0.012 \\
\hline $100 \mathrm{ng}$ & 0.182 & 0.034 & $1 \mu \mathrm{g}$ & 0.156 & 0.014 & $0.189^{\neq}$ & 0.028 & 0.113 & 0.023 \\
\hline $10 \mathrm{ng}$ & 0.176 & 0.044 & $100 \mathrm{ng}$ & 0.166 & 0.032 & $0.178^{\neq}$ & 0.031 & $0.127^{*}$ & 0.019 \\
\hline $1 \mathrm{ng}$ & $0.132 *$ & 0.014 & $10 \mathrm{ng}$ & 0.141 & 0.015 & $0.163^{\neq}$ & 0.016 & $0.149^{*}$ & 0.050 \\
\hline $1 \mathrm{pg}$ & 0.149 & 0.024 & $1 \mathrm{ng}$ & 0.147 & 0.029 & $0.153^{\neq}$ & 0.024 & $0.115^{*}$ & 0.011 \\
\hline ANOVA & $<0.0002$ & & ANOVA & 0.0003 & & $<0.0001$ & & 0.0350 & \\
\hline 3 days & Mean & S.D. & 3 days & Mean & S.D. & Mean & S.D. & Mean & S.D. \\
\hline Control & 0.286 & 0.063 & Control & 0.367 & 0.089 & 0.092 & 0.018 & 0.183 & 0.073 \\
\hline $100 \mu \mathrm{g}$ & 0.285 & 0.036 & $1 \mathrm{mg}$ & $0.122^{\neq}$ & 0.011 & $0.261^{\neq}$ & 0.079 & 0.168 & 0.023 \\
\hline $10 \mu \mathrm{g}$ & 0.336 & 0.062 & $100 \mu \mathrm{g}$ & 0.352 & 0.053 & $0.370^{\neq}$ & 0.142 & 0.189 & 0.025 \\
\hline $1 \mu \mathrm{g}$ & $0.385^{*}$ & 0.096 & $10 \mu \mathrm{g}$ & 0.344 & 0.030 & $0.358^{\neq}$ & 0.152 & $0.219 *$ & 0.050 \\
\hline $100 \mathrm{ng}$ & 0.335 & 0.055 & $1 \mu \mathrm{g}$ & 0.392 & 0.074 & $0.326^{\neq}$ & 0.089 & $0.240^{+}$ & 0.064 \\
\hline $10 \mathrm{ng}$ & 0.303 & 0.053 & $100 \mathrm{ng}$ & 0.360 & 0.047 & $0.386^{\neq}$ & 0.167 & $0.216^{*}$ & 0.031 \\
\hline $1 \mathrm{ng}$ & 0.334 & 0.080 & $10 \mathrm{ng}$ & 0.329 & 0.059 & $0.309^{\neq}$ & 0.060 & 0.2085 & 0.030 \\
\hline $1 \mathrm{pg}$ & 0.245 & 0.0467 & $1 \mathrm{ng}$ & 0.321 & 0.058 & $0.294^{\neq}$ & 0.084 & 0.203 & 0.060 \\
\hline ANOVA & 0.0003 & & ANOVA & $<0.0001$ & & $<0.0001$ & & 0.0397 & \\
\hline 7 days & Mean & S.D. & 7 days & Mean & S.D. & Mean & S.D. & Mean & S.D. \\
\hline Control & 0.459 & 0.120 & Control & 0.562 & 0.162 & 0.377 & 0.098 & 0.224 & 0.041 \\
\hline $100 \mu \mathrm{g}$ & 0.560 & 0.104 & $1 \mathrm{mg}$ & $0.193^{\neq}$ & 0.022 & $0.622 *$ & 0.310 & 0.229 & 0.044 \\
\hline $10 \mu \mathrm{g}$ & 0.547 & 0.091 & $100 \mu \mathrm{g}$ & 0.677 & 0.232 & $0.657^{\neq}$ & 0.099 & 0.275 & 0.080 \\
\hline $1 \mu \mathrm{g}$ & 0.595 & 0.1415 & $10 \mu \mathrm{g}$ & 0.569 & 0.205 & $0.570^{+}$ & 0.104 & 0.247 & 0.0594 \\
\hline $100 \mathrm{ng}$ & 0.489 & 0.106 & $1 \mu \mathrm{g}$ & 0.524 & 0.138 & $0.507 *$ & 0.168 & 0.285 & 0.121 \\
\hline $10 \mathrm{ng}$ & 0.562 & 0.167 & $100 \mathrm{ng}$ & 0.6562 & 0.1488 & $0.599^{\neq}$ & 0.1166 & 0.284 & 0.0889 \\
\hline $1 \mathrm{ng}$ & 0.526 & 0.1783 & $10 \mathrm{ng}$ & 0.652 & 0.214 & $0.591 *$ & 0.193 & 0.288 & 0.070 \\
\hline $1 \mathrm{pg}$ & 0.533 & 0.197 & $1 \mathrm{ng}$ & $0.449 *$ & 0.073 & $0.547 *$ & 0.1011 & 0.251 & 0.076 \\
\hline ANOVA & 0.49623 & & ANOVA & & $<0.0001$ & 0.0127 & & 0.3485 & \\
\hline
\end{tabular}

Note: ${ }^{*} \mathrm{p}<0.05 ;{ }^{+} \mathrm{p}<0.005 ;{ }^{\neq} \mathrm{p}<0.0005$. 


\section{Total Protein}

Intracellular total protein amount was significantly increased by the addition of $1 \mathrm{mg} / \mathrm{ml}$ CHD-1 for 7 days $(\mathrm{p}<0.05$ ); the protein titer in the culture media did not show any statistically significant change. The intracellular total protein content decreased significantly in the study of $100 \mu \mathrm{g} / \mathrm{ml}$ CHD-6 for 1 day ( $\mathrm{p}<0.005), 3$ days $(\mathrm{p}=0.005)$ and 7 days $(\mathrm{p}<0.05)$. In the bone cell culture with CHD-10, the protein amount in culture medium increased significantly at 1,3 and 7 days $(\mathrm{p}<0.05)$, but the intracellular total protein amount did not change. There is no significant change in both the intracellular total protein amount and protein amount of medium for $1 \mu \mathrm{g} / \mathrm{ml} \mathrm{CHD}-2$ (Fig. 1).
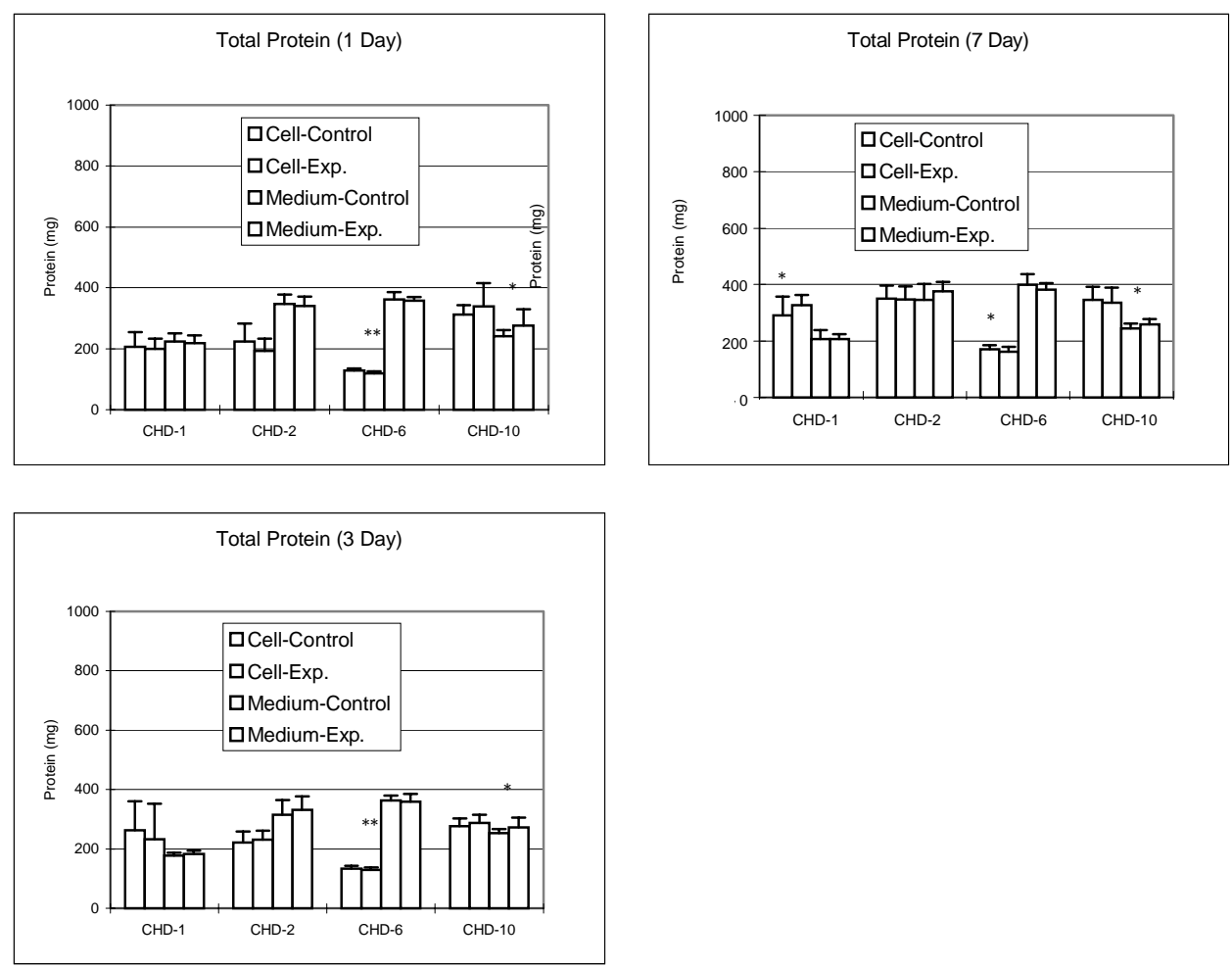

Figure 1. Changes in protein titer after adding various Chinese medicines into the bone cell culture. CHD-1 $(1 \mathrm{mg} / \mathrm{ml})$ can significantly increase the intracellular protein titer $(\mathrm{p}<0.05)$ but without any changes in the protein titer in the culture media. CHD-10 $(1 \mathrm{mg} / \mathrm{ml})$ can significantly increase the protein titer in the medium $(p<0.05)$ but without any changes in the intracellular protein titer of the bone cells. There is no significant change in both the intracellular total protein amount and protein amount of medium for $1 \mu \mathrm{g} / \mathrm{ml} \mathrm{CHD}-2$ $(* \mathrm{p}<0.05 ; * * \mathrm{p}<0.005 ; * * * \mathrm{p}<0.0005)$. 


\section{Lactate Dehydrogenase}

Intracellular content of LDH in bone cell culture of various CHD preparations are shown in Fig. 2. After 1 day bone cell culture, intracellular LDH content in the culture with CHD-10 was significantly increased, while significantly decreased in the culture with CHD-2 $(\mathrm{p}<0.05)$. Otherwise, there is no significant change in LDH titer noted during the experimental period (Fig. 2).
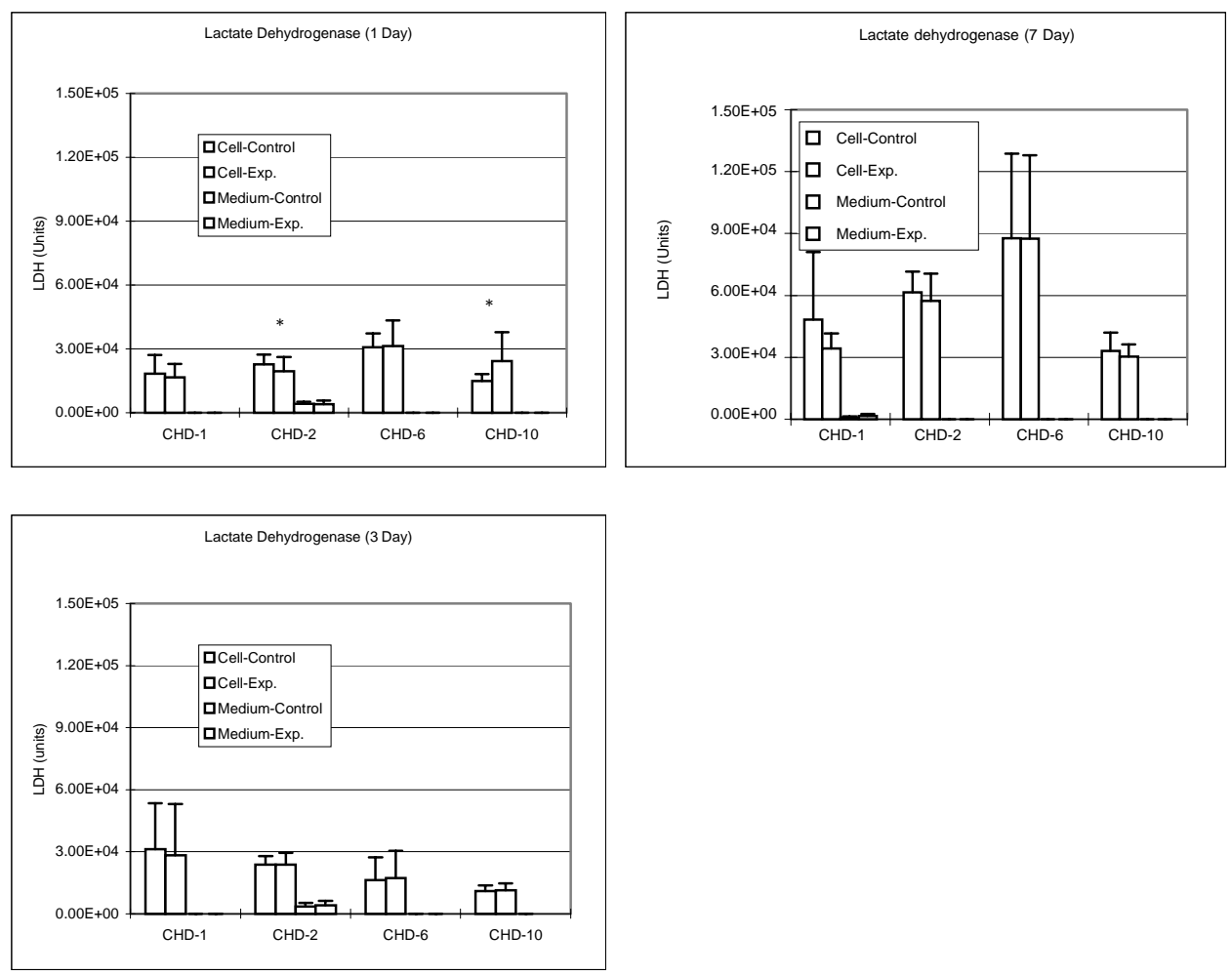

Figure 2. Changes in LDH titer after adding various Chinese medicines into the bone cell culture. Intracellular LDH content in the medium was increased after the bone cells were cultured with CHD-10 for 1 day $(\mathrm{p}<0.05)$, but significantly decreased in CHD-2 culture $(\mathrm{p}<0.05)$. Otherwise, there is no significant change in LDH titer noted during the experimental period $(* \mathrm{p}<0.05 ; * * \mathrm{p}<0.005 ; * * * \mathrm{p}<0.0005)$. 


\section{Alkaline Phosphatase}

Total ALP amount in culture medium was significantly increased by the addition of $1 \mu \mathrm{g} /$ $\mathrm{ml} \mathrm{CHD}-2$ for 1 day ( $\mathrm{p}<0.05$ ), but decreased significantly by $1 \mathrm{mg} / \mathrm{ml} \mathrm{CHD}-1$ and $100 \mu \mathrm{g} /$ $\mathrm{ml}$ CHD-6 for 3 days ( $\mathrm{p}<0.005$ ) to the bone cell culture. Intracellular total ALP synthesis was significantly increased by the addition of $1 \mathrm{mg} / \mathrm{ml} \mathrm{CHD}-1$ for 7 days $(\mathrm{p}<0.05)$. There is no significant increase in the intracellular total ALP amount for $1 \mu \mathrm{g} / \mathrm{ml} \mathrm{CHD-2}$; while for CHD-10, both intracellular ALP synthesis and ALP in medium did not show any significant change during the experimental period (Fig. 3).
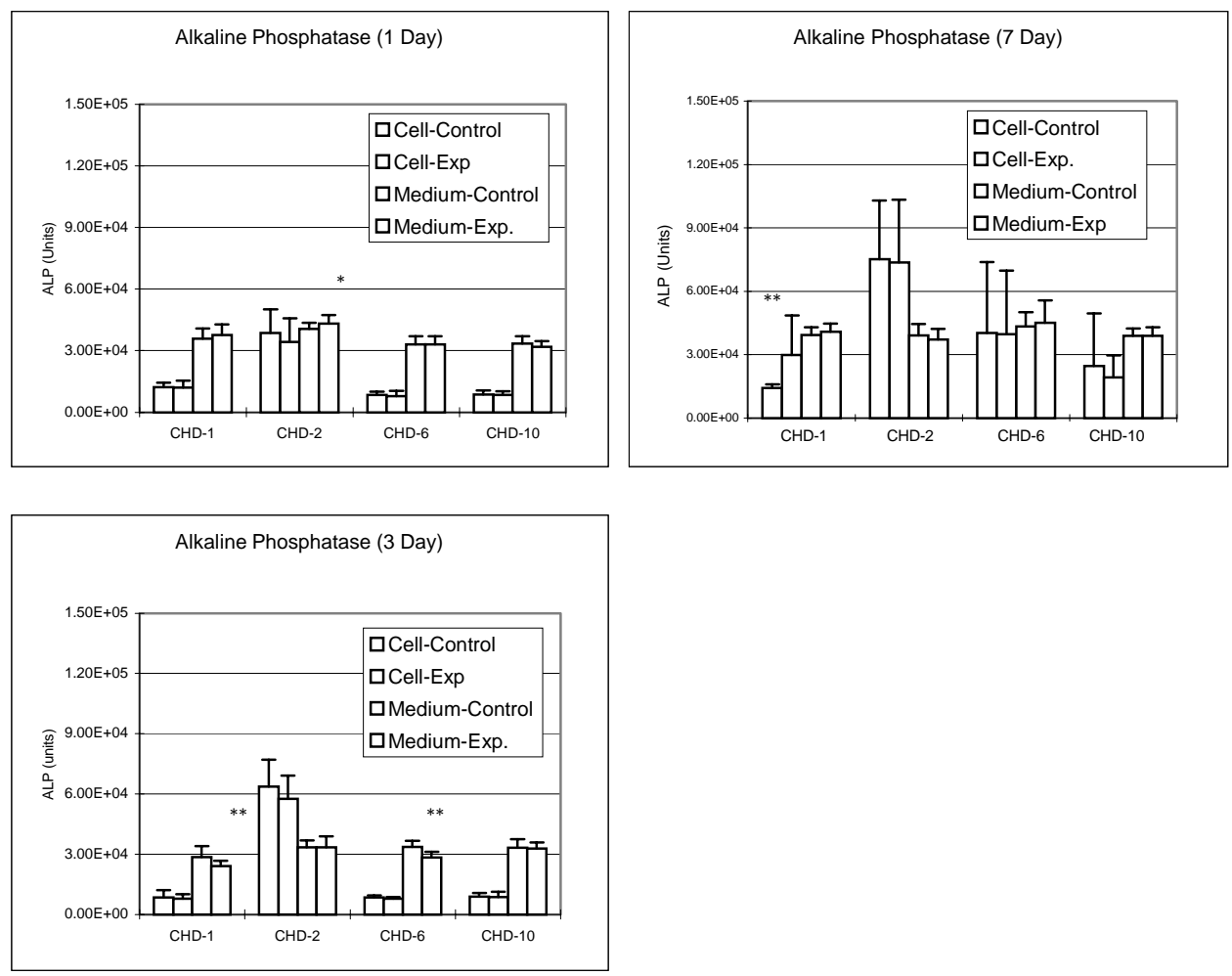

Figure 3. Changes in total ALP titer after adding various Chinese medicines into the bone cell culture. ALP amount in culture medium was significantly increased by the addition of $1 \mu \mathrm{g} / \mathrm{ml} \mathrm{CHD}-2$ (for 1 day; $\mathrm{p}<0.05$ ) to bone cell culture; but was significantly decreased by the addition of $1 \mathrm{mg} / \mathrm{ml} \mathrm{CHD}-1$ (for 3 days; $\mathrm{p}<0.005$ ) and $100 \mu \mathrm{g} / \mathrm{ml}$ CHD-6 (for 3 days; $\mathrm{p}<0.005$ ). Intracellular total ALP synthesis was also significantly increased by the addition of $1 \mathrm{mg} / \mathrm{ml} \mathrm{CHD}-1$ for 7 days $(\mathrm{p}<0.05)$ and $100 \mu \mathrm{g} / \mathrm{ml}$ CHD- 6 for 3 days $(\mathrm{p}<0.05)(* \mathrm{p}<0.05$; $* * \mathrm{p}<0.005 ; * * * \mathrm{p}<0.0005)$. 


\section{Acid Phosphatase}

After adding $1 \mathrm{mg} / \mathrm{ml}$ of CHD-1 to the bone cell culture, the ACP amount in culture medium was significantly increased during the 7 days experimental period $(\mathrm{p}<0.0005)$; while the intracellular ACP amount were significantly increased in the 1 day and 7 days culture ( $\mathrm{p}<0.05$ ) (Fig. 4). Adding of $1 \mu \mathrm{g} / \mathrm{ml} \mathrm{CHD-2} \mathrm{into} \mathrm{bone} \mathrm{cell} \mathrm{culture} \mathrm{will} \mathrm{significantly}$ decrease the intracellular ACP amount after 1 day $(\mathrm{p}<0.005)$ culture and the ACP amount in the culture medium increased at 3 days $(\mathrm{p}=0.05$ ) culture (Fig. 4). Adding of $1 \mathrm{mg} / \mathrm{ml}$ CHD-10 into bone cell culture decreased the ACP amount in the medium at 3 days $(\mathrm{p}=0.05)$ culture period (Fig. 4$)$.
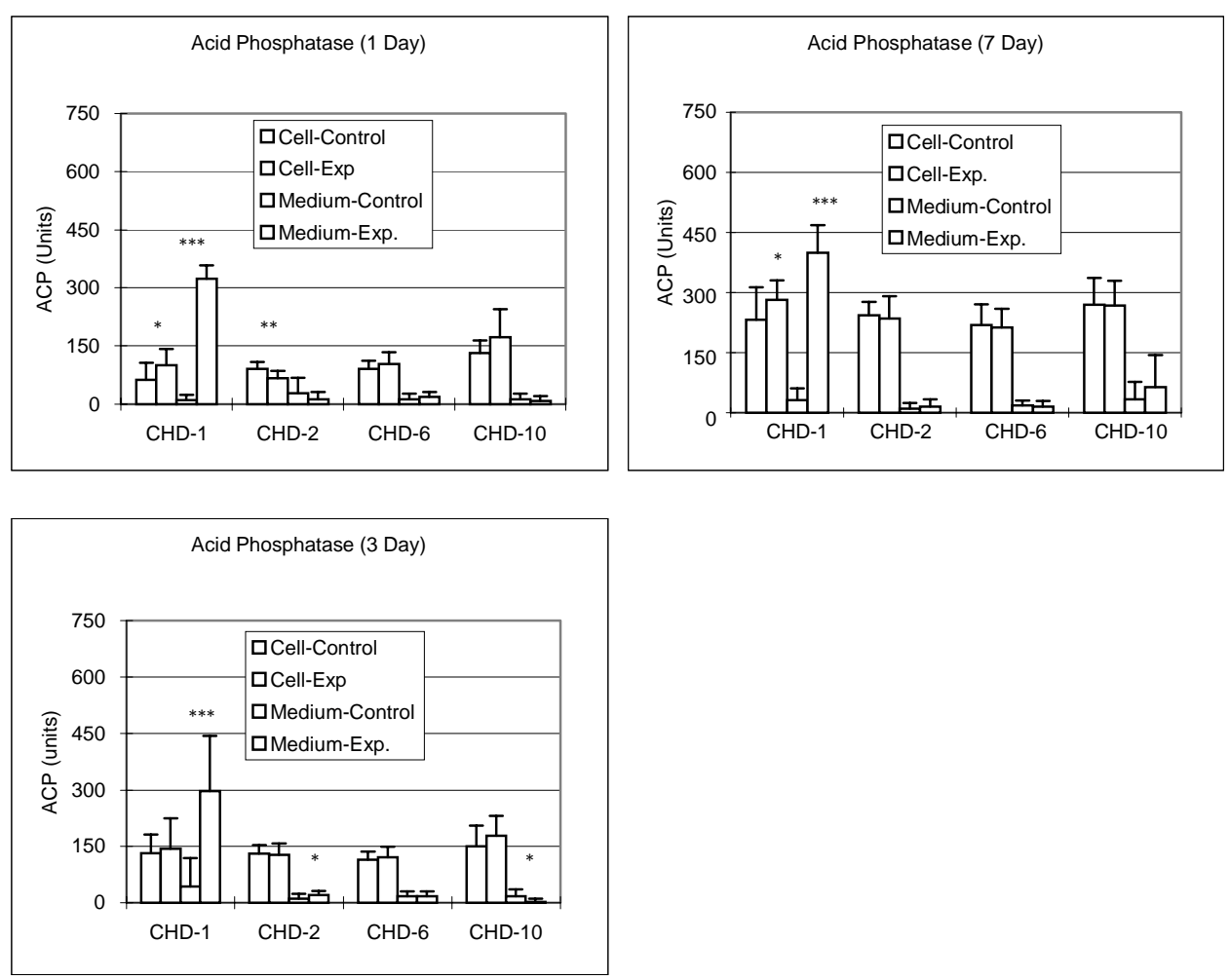

Figure 4. Changes in total ACP titer after adding various Chinese medicines into the bone cell culture. After adding $1 \mathrm{mg} / \mathrm{ml}$ of CHD- 1 and $1 \mu \mathrm{g} / \mathrm{ml} \mathrm{CHD}-2$ into the bone cell culture, both the intracellular ACP titer and the ACP amount in culture medium were significantly increased ( $\mathrm{p}<0.05$ ). Adding of $100 \mu \mathrm{g} / \mathrm{ml}$ CHD-6 or $1 \mathrm{mg} /$ $\mathrm{ml} \mathrm{CHD}-10$ into the bone cell culture increased the ACP amount in the medium at 3 days $(\mathrm{p}=0.05)$ culture period $(* \mathrm{p}<0.05 ; * * \mathrm{p}<0.005 ; * * * \mathrm{p}<0.0005)$. 


\section{In Situ Detection of Apoptosis of Osteoclasts after CHD-1 Treatment}

The osteoclasts undergoing apoptosis after CHD-1 treatment can be clearly seen with the in situ immunohistochemical stain for apoptosis. After 1 day CHD-1 treatment on bone cells, the apoptosis of the osteoclasts was detected in the osteoclasts clusters as shown by the dense staining in the samples (Fig. 5). The apoptosis of osteoclasts was even more significant after 3 days treatment of CHD-1 as manifested by the pyknotic changes in the nucleus of the osteoclasts giant cells (Fig. 5). After 7 days CHD-1 treatment, there is loss of cellularity in the center of osteoclasts giant cells and some residual apoptotic cells with pyknotic nucleus visible, but the surrounding osteoblasts populations were relatively preserved (Fig. 5).

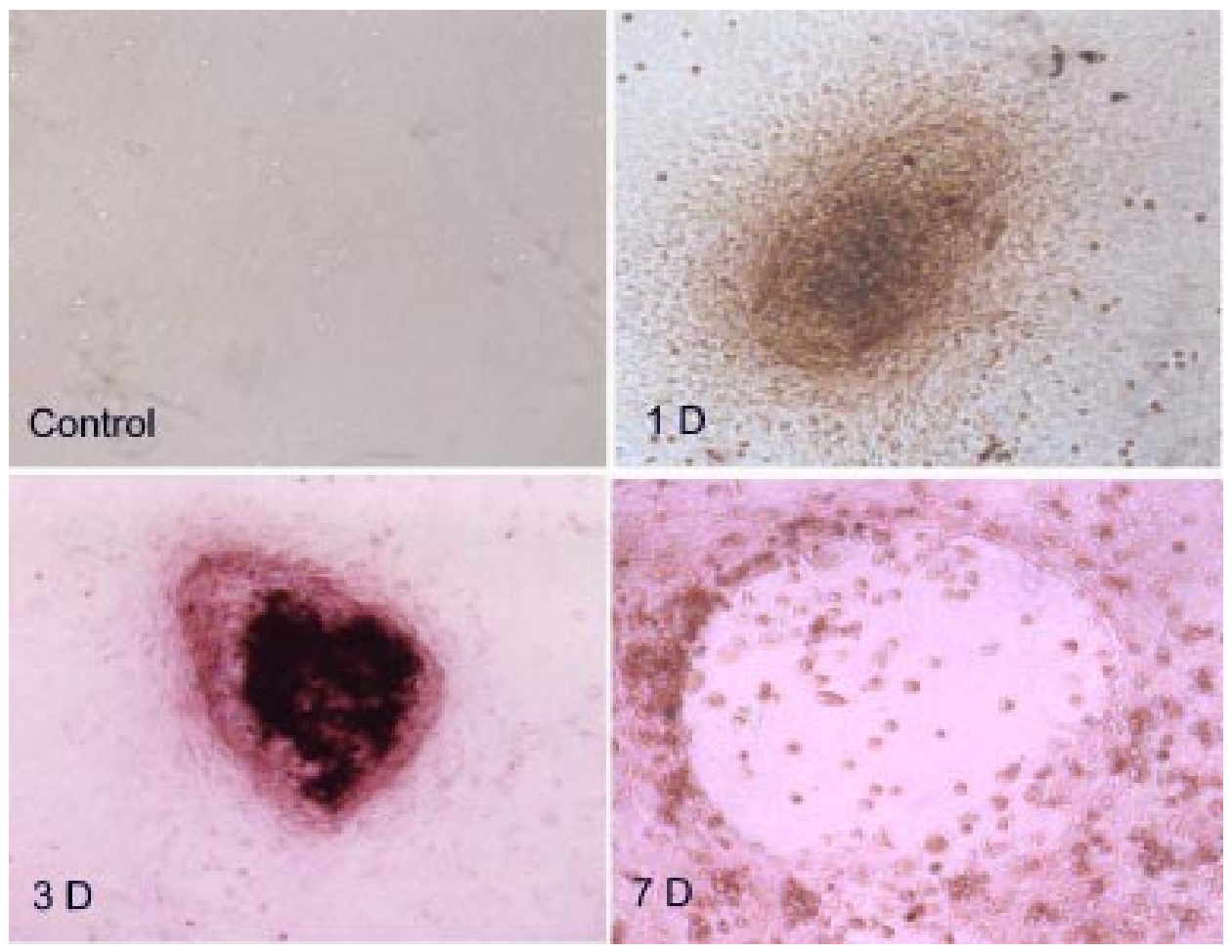

Figure 5. The in situ immunohistochemical stain for apoptosis after CHD-1 treatment. Control: In the control groups of bone cell culture, there was no evidence of apoptotic changes after 7 days culture. 1D: After 1 day CHD-1 treatment on bone cells, the apoptosis of the osteoclasts was detected in the osteoclasts clusters by showing dense stain in the samples. 3D: The apoptosis of osteoclasts was even more significant after 3 days treatment of CHD-1 as manifested by the pyknotic changes in the nucleus of the osteoclasts giant cells. 7D: After 7 days CHD-1 treatment, there is loss of cellularity in the center of osteoclasts giant cells and some residual apoptotic cells with pyknotic nucleus visible, but the surrounding osteoblasts populations were relatively preserved. 


\section{Discussion}

There are several reports demonstrating improvement in clinical association with the use of traditional Chinese medicines in treatment of fractures (Huang and You, 1997). Despite encouraging preliminary reports, basic science and clinical reports justifying the clinical application of specific Chinese medicines are still not well established. The specific biological advantages which can be obtained from the Chinese medicines must include faster and more uniform bone ingrowths (Huang and You, 1997). Additionally, more evidence must indicate that specific Chinese medicines help to promote bone cell proliferation and differentiation. This study has attempted to establish the relationship between bone cells and various Chinese medicines which may contribute to the possible justification for the clinical application in the treatment of bone disease.

Addition of Chinese medicines into the culture medium will significantly affect bone cell metabolism. As noted in this study, intracellular total protein amount was significantly increased by the addition of CHD-1, but without affecting protein titer in the culture media. In the bone cell culture with CHD-10, the protein amount in culture medium significantly increased, but the intracellular total protein amount did not change. There is no significant change in both the intracellular total protein amount and protein amount of medium for CHD-2 (Fig. 1). This reflected that CHD-1 can greatly increase proliferative and biosynthetic capacities of bone cell cultures.

LDH is a cytoplasmic enzyme present within all mammalian cells. The plasma membrane is normally impermeable to $\mathrm{LDH}$ and the enzyme is only released into the extracellular fluid when the membrane has been damaged. The release of LDH is, therefore, a sensitive and accurate marker for cytotoxicity. Assays for LDH have been used in immunology for detecting cellular cytotoxicity (Decker and Lohmann-Matthes, 1988), and in biocompatibility studies for measuring the toxicity of biomaterials in vitro. Cytotoxicity results were expressed as percentage $\mathrm{LDH}$ release against time for each test material. In this study, $\mathrm{LDH}$ content in the culture with CHD-10 was increased after 1 day bone cell culture $(\mathrm{p}<0.05)$, otherwise, there is no significant change in LDH titer noted during the experimental period. This means that CHD-1, -2, -6 and -10 had little or no cytotoxic effect.

Both the intracellular total ALP amount and the ALP secreted in medium were significantly increased after the addition of CHD-1 regimen. For the CHD-10 preparation, both the intracellular total ALP amount and the ALP secreted in medium did not show any significant change during the experimental period. The total ALP secretion into media was significantly decreased in the CHD-6 preparation; while total ALP secretion into media was significantly increased in the CHD-2 preparation (Fig. 3). This means different preparations of Chinese medicines had different effects on the osteoblasts cell activities. Therefore, it seems that CHD-1 has the most potential beneficial effect on the osteoblasts.

It is well established that osteoclasts, specialized multinucleated giant cells responsible for bone resorption, i.e. osteoclasts, were derived from activated macrophages and play a role in the direct lysis of bone. Osteoclasts can resorb devitalized bone in vitro and exhibit osteoclast-like characteristics, including formation of clear zones and release of the lysosomal enzyme ACP at the bone-cell interface (Kahn et al., 1978; Teitelbaum et al., 1979). After 
adding of CHD-1 and -2 into bone cell culture, both the intracellular ACP amount and the $\mathrm{ACP}$ in culture medium were significantly increased during the experimental period (Fig. 4). Addition of $100 \mu \mathrm{g}$ CHD-6 or $1 \mathrm{mg}$ CHD-10 into bone cell culture increased only the ACP amount in the medium; the intracellular ACP did not show any significant changes (Fig. 4). As noted above, addition of CHD-1 into bone cell culture can significantly increase intracellular protein synthesis (Fig. 1). This fact combined with the results of ALP changes probably imply that the addition of CHD-1 regimen resulted in significant enhancement of bone cell activities.

To clarify the possible mechanism of CHD-1 on bone cell viability, immunohistochemical studies were performed. We already know that there are two distinct modes of cell death apoptosis and necrosis - which can be distinguished based on differences in morphological, biochemical and molecular changes of dying cells. Programmed cell death or apoptosis is the most common form of eukaryotic cell death (Kerr et al., 1972). In general, cells undergoing apoptosis display a characteristic pattern of structural changes in nucleus and cytoplasm, including rapid blebbing of plasma membrane and nuclear disintegration. The nuclear collapse is associated with extensive damage to chromatin and DNA cleavage into oligonucleosomal length DNA fragments after activation of a calcium-dependent endogenous endonuclease (Compton, 1992). In the TUNEL technique, DNA polymerase as well as terminal deoxynucleotidyl transferase (TdT) have been used for the incorporation of labeled nucleotides to DNA strand breaks in situ (Sgonc et al., 1994; Gavrieli et al., 1992; Mochizuki et al., 1994; Portera-Cailliau et al., 1994). In this study, the osteoclasts undergoing apoptosis after CHD-1 treatment was quite obvious with the in situ TUNEL stain for apoptosis (Fig. 5). After 1 day CHD-1 treatment on bone cell culture, the apotosis stain was detected in the osteoclasts. The decrease in the cellularity and apoptosis stain of osteoclasts was even more significant after 3 days and 7 days treatment of CHD-1 (Fig. 5). These findings suggest that CHD-1 may selectively induce the apoptosis of the osteoclasts cell populations.

In summary, despite encouraging preliminary clinical reports about clinical improvement with the use of traditional Chinese medicines, basic science and controlled studies reported to date have controversial results. As noted in this study, only four out of ten Chinese medicines have potential beneficial effects on bone cell culture; and of these four, only CHD-1 [Drynaria fortunei (Kunze) J. Sm.] have universal beneficial effects on bone cell metabolism. One of the major beneficial effects of CHD-1 on bone cells is probably mediated by the induction of apoptosis of osteoclasts cell population. Although our study had limitations and our findings are preliminary, there appears to be little justification for the universal use of traditional Chinese medicines in primary treatment of bone diseases. Continued and advanced investigations into the alterations in gene expression of bone cells by Chinese medicines will provide a basis for the understanding of bone cell responses to various pharmacological interventions.

\section{Acknowledgments}

The authors sincerely thank the National Health Research Institutes (ROC) for their financial support of this research. 


\section{References}

Campbell, C.J. The healing of cartilage defects. Clin. Orthop. 64: 45,1969.

Compton, M.M. A biochemical hallmark of apoptosis: internucleosomal degradation of the genome. Cancer Metastasis Rev. 11: 105-119, 1992.

Crane, G.M., S.L. Ishaug and A.G. Mikos. Bone tissue engineering. Nature Med. 1: 1322-1324, 1995.

Decker, T. and M.L. Lohmann-Matthes. A quick and simple method for the quantitation of lactate dehydrogenase release in measurements of cellular cytotoxicity and tumor necrosis factor (TNF) activity. J. Immunol. Methods 115: 61-69, 1988.

Gavrieli, Y., Y. Sherman and S.A. Ben-Sasson. Identification of programmed cell death in situ via specific labeling of nuclear DNA fragmentation. J. Cell Biol. 119: 493-501, 1992.

Huang, H.F. and J.S. You. The use of Chinese herbal medicine on experimental fracture healing. Am. J. Chin. Med. 25: 351-356, 1997.

Kahn, A.J., C.C. Stewart and S.L. Teitelbaum. Contact-mediated bone resorption by human monocytes in vitro. Science 199: 988-990, 1978.

Kerr, J.F., A.H. Wyllie and A.R. Currie. Apoptosis: a basic biological phenomenon with wide-ranging implications in tissue kinetics. Br. J. Cancer 26: 239-257, 1972.

Mochizuki, H., N. Nakamura, K. Nishi and Y. Mizuno. Apoptosis is induced by 1-methyl-4phenylpyridinium ion (MPP+) in ventral mesencephalic-striatal co-culture in rat. Neurosci. Lett. 170: 191-194, 1994.

Mosmann, T. Rapid colorimetric assay for cellular growth and survival: application to proliferation and cytotoxicity assay. J. Immunol. Methods 65: 55-63, 1983.

Portera-Cailliau, C., C.H. Sung, J. Nathans and R. Adler. Apoptotic photoreceptor cell death in mouse models of retinitis pigmentosa. Proc. Natl. Acad. Sci. USA 91: 974-978, 1994.

Sgonc, R., G. Boeck, H. Dietrich, J. Gruber, H. Recheis and G. Wick. Simultaneous determination of cell surface antigens and apoptosis. Trends Genet. 10: 41-42, 1994.

Smith, R. Collagen and disorders of bone. Clin. Sci. 59: 215-223, 1980.

Sun, J.S., W.H.S. Chang, R.C. Hong, T.Y. Hung, F.H. Lin and H.C. Liu. Alveolar mononuclear cells can develop into multinucleated osteoclasts: an in vitro cell culture model. J. Biomed. Mater. Res. 52: 142-147, 2000.

Teitelbaum, S.L., C. Stewart and A.J. Kahn. Rodent peritoneal macrophages as bone resorbing cells. Calcif. Tissue Int. 27: 255-261, 1979.

WHO Technical Report Series, No. 843. Assessment of Fracture Risk and Its Application to Screening for Postmenopausal Osteoporosis, Report of a WHO Study Group. World Health Organization, Geneva, 1994 (WHO Technical Report Series, No. 843). 